\title{
Genes do eixo somatotrófico e características de crescimento numa população $F_{2}$ de bovinos
}

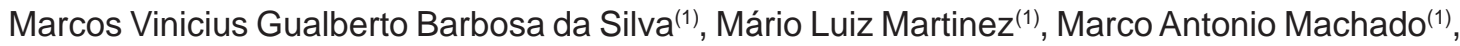 \\ Carlos Souza do Nascimento( ${ }^{(2)}$, Ana Lúcia Campos ${ }^{(1)}$, Marta Fonseca Martins Guimarães ${ }^{(1)}$, \\ Ana Luisa Sousa Azevedo(1), Antônia Kécya França Moita ${ }^{(3)}$ e Jeffrey Frederico Lui(3)
}

\begin{abstract}
(1)Embrapa Gado de Leite, Rua Eugênio do Nascimento, no 610, Dom Bosco, CEP 36038-330 Juiz de Fora, MG. E-mail: marcos@cnpgl.embrapa.br, martinez@cnpgl.embrapa.br, machado@cnpgl.embrapa.br, alcampos@cnpgl.embrapa.br, mmartins@cnpgl.embrapa.br, luisasousa35@yahoo.com.br (2)Universidade Federal de Minas Gerais, Escola de Veterinária, Av. Antônio Carlos, no 6627, Caixa Postal 567, CEP 30123-970 Belo Horizonte, MG. E-mail: carsouza100@yahoo.com.br (3)Universidade Estadual Paulista, Fac. de Ciências Agrárias e Veterinária, Campus Jabotical, Dep. de Zootecnia, Av. Prof. Paulo Donato Castellane, s/no, CEP 14884-900 Jaboticabal, SP. E-mail: kecyamoita@yahoo.com.br, jeffrey@fcav.unesp.br
\end{abstract}

Resumo - O objetivo deste trabalho foi avaliar a associação dos polimorfismos dos genes bGH, IGF-1 e PIT-1 com características de peso e ganho de peso numa população $\mathrm{F}_{2}$ de bovinos (Gir x Holandês), pela técnica de PCR-RFLP. As freqüências alélicas A e B, do gene PIT-1, e dos genótipos AA, AB e BB, nas populações parentais foram semelhantes entre si, mas diferentes das freqüências nas populações cruzadas $F_{1}$ e $F_{2}$, para esse gene. Quanto ao gene bGH, os animais da raça Holandesa apresentaram freqüência de 100\% para o alelo E e os animais da raça Gir, 92\% para o alelo $\mathrm{F}$, resultando em alta freqüência de indivíduos heterozigotos nas populações $\mathrm{F}_{1}$ e $F_{2}$. Quanto ao gene IGF-1, todos os animais da raça Holandesa eram heterozigotos (AB) e, nos animais Gir, a maioria dos indivíduos foi de homozigotos (AA), o que resultou em alta freqüência do alelo A nas populações $\mathrm{F}_{1}$ e $\mathrm{F}_{2}$. Foram encontradas associações significativas do alelo A do gene PIT-1 com as características de peso aos 60, 205, 365 dias e ganho de peso do nascimento aos 60 dias. Em bGH, observou-se efeito significativo do alelo E para peso aos 365 dias e ganho de peso do nascimento aos 60 dias, enquanto o efeito do alelo A do IGF-1 foi significativo somente para peso ao nascimento. Os alelos identificados podem ser usados como marcadores no melhoramento animal.

Termos para indexação: marcadores moleculares, PCR-RFLP.

\section{Somatotrophic axis genes on growth traits in a bovine $F_{2}$ population}

\begin{abstract}
The objective of this work was to evaluate the association between polymorphisms of bGH, IGF-1 and PIT-1 genes with weight and weight gain traits in a bovine $\mathrm{F}_{2}$ population derived from Holstein $\mathrm{x}$ Gyr crosses, using the PCR-RFLP technique. Allelic frequencies A and $B$ of PIT-1 gene and AA, AB, and BB genotypes were similar between parental populations but different from $\mathrm{F}_{1}$ and $\mathrm{F}_{2}$ crossed populations. For the bGH gene, Holstein animals showed allelic frequency of $100 \%$ for $\mathrm{E}$ allele, while Gyr animals showed allelic frequency of $92 \%$ for $\mathrm{F}$ allele, resulting in high frequency of heterozygous animals in $\mathrm{F}_{1}$ and $\mathrm{F}_{2}$ populations. For the IGF-1 gene, all Holstein were heterozygous (AB) and most Gyr were homozygous (AA), resulting in a high frequency of $A$ allele in $F_{1}$ and $F_{2}$ populations. Significant associations were found between PIT-1 allele A with traits weight at 60, 205 and 365 days and weight gain from birth to 60 days. For IGF-1, significant association was found between A allele and birth weight. For bGH gene, significant associations were found between E allele and 365 days weight and weight gain from birth to 60 days. The selected alleles could be used as markers in animal breeding for these traits.
\end{abstract}

Index terms: molecular markers, PCR-RFLP.

\section{Introdução}

Os genes que influenciam as características poligênicas são de difícil identificação. Atualmente, um número razoável de genes candidatos relacionados às características poligênicas, como crescimento em bovinos, tem sido estudado. Um exemplo é o dos genes que compõem o eixo somatotrófico, envolvido nas características de crescimento do indivíduo. Mutações nos genes responsáveis por etapas desse eixo podem prejudicar o crescimento e desenvolvimento do animal. 
Os distúrbios de crescimento podem ser decorrentes da deficiência do hormônio do crescimento bovino (bGH) e outros hormônios hipofisários, como o fator de transcrição da pituitária (PIT-1), por alterações em fatores de transcrição envolvidos na organogênese hipofisária; da deficiência isolada de bGH; e da insensibilidade ao bGH, com níveis indetectáveis de IGF-1 (fator de crescimento semelhante à insulina).

O gene PIT-1, pertencente à grande família de POU - acrônimo de Pit, Oct 1 e Unc - dos genes homeobox, foi mapeado no cromossomo 1 dos bovinos e é um fator de regulação para a síntese do bGH, prolactina e tirotropina (Oprzadek et al., 2003). De acordo com Brunsch et al. (2002), mutações no gene PIT-1 foram relatadas em camundongos-anões e, mais tarde, em famílias de genes humanos, as quais estavam combinadas com deficiências de hormônios da glândula pituitária anterior. Woolard et al. (1994) verificaram, por meio da técnica de PCR-RFLP, a existência de dois alelos (Hinf I- e Hinf I ${ }^{+}$) para o sítio Hinf I, no exon 6.

A avaliação desse tipo de polimorfismo sobre características ligadas ao crescimento corporal foi feita por Renaville et al. (1997b), os quais verificaram associação positiva com a profundidade corporal em touros da raça Holandesa, na Itália. Ao estudarem o efeito do gene PIT-1 sobre a musculatura dupla na raça Belgian Blue, Renaville et al. (1997a) verificaram que o genótipo BB estava significativamente associado a maiores pesos ao nascimento e aos 205 dias de idade.

O gene GH é necessário para o crescimento normal dos mamíferos, influenciando a taxa de crescimento e todo o metabolismo do animal (Bernal, 1990). É sintetizado no lóbulo anterior da glândula hipófise, mais precisamente na adenohipófise e está relacionado a estímulos dos processos anabólicos como a divisão celular, o crescimento esquelético e a síntese protéica. Tais constatações foram feitas por Neathery et al. (1991), os quais administraram doses de GH exógeno (bST) em animais e verificaram redução de gordura na carcaça e aumento da musculatura corporal. Análises moleculares na seqüência do gene bGH, localizado no cromossomo 19, resultaram na detecção de um sítio polimórfico no exon 5 , no qual a substituição de um nucleotídeo resulta na mudança do aminoácido leucina para valina (Lucy et al., 1991), diferenciando os dois alelos.

O gene IGF-1, também conhecido como somatomedina $\mathrm{C}$, intermedeia efeitos do GH e regula o crescimento e o desenvolvimento pós-natal (Grochowska et al., 2001). Isaksson et al. (1985) afirmaram que o GH age sobre o tecido ósseo, estimulando localmente a produção de IGF-1, levando à diferenciação dos condrócitos, estimulação do crescimento da cartilagem e crescimento longitudinal dos ossos. Mapeado no cromossomo 5 (Miller et al., 1991), esse gene apresenta um polimorfismo para o sítio de restrição SnaB I na região 5'. Moody et al. (1996) relataram que um polimorfismo de microssatélite $(\mathrm{CA})_{\mathrm{n}}$ na região promotora estava associado ao peso ao nascimento e ganho de peso do nascimento ao desmame em uma população Hereford.

A utilização combinada da seleção tradicional, baseada no desempenho fenotípico, e da seleção assistida por marcadores moleculares (MAS), em alelos que se mostrem favoravelmente relacionados às características de crescimento, aumentará a eficiência dos programas de melhoramento genético. Segundo Abdel-Azim \& Freeman (2002), o uso de MAS para pré-seleção de touros jovens, em esquemas de teste de progênie, pode aumentar o ganho genético em $7,6 \%$.

O objetivo deste trabalho foi avaliar a associação entre alelos dos genes candidatos PIT-1, bGH e IGF-1 e características relacionadas ao crescimento em uma população $F_{2}$ de bovinos, resultante do cruzamento entre animais $F_{1}$ (1/2 Holandês:1/2 Gir).

\section{Material e Métodos}

Os animais $\mathrm{F}_{2}$ utilizados foram produzidos no Campo Experimental Santa Mônica, da Embrapa Gado de Leite, em Valença, RJ. Esta população foi originada dos cruzamentos entre animais $F_{1}$ (1/2 Holandês:1/2 Gir). Em uma primeira fase, foram utilizadas 28 fêmeas Gir (em trabalho de superovulação e transferência de embriões), inseminadas com sêmen de quatro touros da raça Holandesa. Foram usadas, como receptoras, cerca de 300 fêmeas Holandês x Gir, cuja composição genética variou de 1/2 a 7/8, entre novilhas e vacas adultas em lactação.

Os acasalamentos foram repetidos com a finalidade de se obter cerca de $150 \mathrm{~F}_{1}$ : quatro machos foram escolhidos, com base no vigor, para serem pais da nova geração $F_{2}$. Sessenta fêmeas $F_{1}$ foram acasaladas com cada um dos quatro touros, para constituírem quatro famílias, evitando-se o parentesco entre o reprodutor e as fêmeas a ele designadas. 
Os bezerros, logo depois do nascimento, foram induzidos a ingerir o colostro, permanecendo junto às mães durante as primeiras 24 horas de vida para ter acesso livre ao colostro, período no qual são pesados. Em seguida, foram levados para gaiolas individuais, recebendo $4 \mathrm{~L}$ de leite por dia, além de feno, ração concentrada e água à vontade até os 56 dias. Depois dessa idade, foram agrupados em lotes, de acordo com a idade, e recriados em piquetes de grama-estrela (Cynodon nlemfuensis), até a idade de 12 meses, quando foram transferidos para pastos de braquiária (Brachiaria sp.). Os animais foram pesados no nascimento e, depois, a cada 28 dias.

Amostras de sangue de 443 animais (quatro touros da raça Holandesa, 27 vacas da raça Gir, seis machos e 67 fêmeas $F_{1}$ Holandês:Gir, 169 machos e 170 fêmeas $F_{2}$ ) foram coletadas e enviadas para o Laboratório de Genética Molecular da Embrapa Gado de Leite para extração de DNA e genotipagem para os genes candidatos PIT-1, bGH e IGF-1. O DNA foi extraído a partir das células brancas das amostras de sangue, utilizando protocolo contendo tampão salino e proteinase $\mathrm{K}$, sendo as proteínas removidas com fenol/ clorofórmio. As amostras de DNA foram analisadas em espectrofotômetro para determinar a quantidade e qualidade. Os polimorfismos dos genes foram analisados pela técnica de PCR-RFLP, que envolve a síntese in vitro de um fragmento de DNA e sua posterior digestão com enzimas de restrição específicas.

A genotipagem para o gene PIT-1 foi realizada segundo Moody et al. (1996). A reação de PCR consistiu de 45 ciclos de $94^{\circ} \mathrm{C}$ por 60 segundos, $56^{\circ} \mathrm{C}$ por 30 segundos e $72^{\circ} \mathrm{C}$ por 60 segundos. Foram utilizados 120 ng de DNA para a reação de PCR contendo uma unidade de Taq DNA polimerase; $100 \mu \mathrm{M}$ de dNTPs; $0,5 \mu \mathrm{M}$ de cada oligonucleotídeo iniciador; $10 \mathrm{mM}$ de Tris-HCl (pH 8,0); 2,5 mM de $\mathrm{MgCl}_{2}$; e $50 \mathrm{mM}$ de $\mathrm{KCl}$; volume final de $15 \mu \mathrm{L}$. Os iniciadores utilizados foram Pit1_F: 5' - CAATGAGAAAGTTGGTGC-3'; e Pit1_R: 5'-TCTGCATTCGAGATGCTC-3', que geraram um produto de 1.355 pb. Do volume final da reação, foram utilizados $10 \mu \mathrm{L}$ para digestão com a enzima Hinf I.

A genotipagem para o gene bGH foi realizada segundo Unanian et al. (2000). A reação de PCR consistiu de 35 ciclos de $94^{\circ} \mathrm{C}$ por 60 segundos, $58^{\circ} \mathrm{C}$ por 60 segundos e $72^{\circ} \mathrm{C}$ por 60 segundos. Foram utilizados 60 ng de DNA para a reação de PCR contendo duas unidades de
Taq DNA polimerase; $400 \mu \mathrm{M}$ de dNTPs; $0,8 \mu \mathrm{M}$ de cada iniciador; $10 \mathrm{mM}$ de Tris- $\mathrm{HCl}(\mathrm{pH}$ 8,0); 1,6 mM de $\mathrm{MgCl}_{2}$; e $50 \mathrm{mM}$ de $\mathrm{KCl}$; volume final de $25 \mu \mathrm{L}$. Os iniciadores utilizados foram GH2_F: 5'-ACGCGCTGCTCAAGAAC-3'; e GH2_R: 5'-GGCTGGAACTAAGAACC-3', que geraram um produto de $441 \mathrm{pb}$. Do volume final da reação, foram utilizados $10 \mu \mathrm{L}$ para digestão com a enzima Hae III.

A genotipagem para o gene IGF-1 foi realizada segundo Ge et al. (2001). A reação de PCR consistiu de 45 ciclos de $94^{\circ} \mathrm{C}$ por 60 segundos, $56^{\circ} \mathrm{C}$ por 30 segundos e $72^{\circ} \mathrm{C}$ por 60 segundos. Foram utilizados $30 \mathrm{ng}$ de DNA para a reação de PCR contendo uma unidade de Taq DNA polimerase; $100 \mu \mathrm{M}$ de dNTPs; $0,5 \mu \mathrm{M}$ de cada iniciador; $10 \mathrm{mM}$ de Tris- $\mathrm{HCl}$ (pH 8,0); 2,5 mM de $\mathrm{MgCl}_{2}$; e $50 \mathrm{mM}$ de $\mathrm{KCl}$; volume final de $15 \mu \mathrm{L}$. Os iniciadores utilizados foram IGF-1_F: 5' - ATTACAAAGCTGCCTGCCCC-3'; e IGF-1_R: 5'-ACCTTACCCGTATGAAAGGAATATACGT-3', que geraram um produto de $249 \mathrm{pb}$. Do volume final da reação, foram utilizados $5 \mu \mathrm{L}$ para digestão com a enzima SnaB I.

Os produtos amplificados nas reações de PCR, para os genes PIT-1, bGH e IGF-1 foram visualizados em géis de poliacrilamida nativo a 5\% (500 volts, por 1 hora). Os géis foram corados com nitrato de prata e os fragmentos foram detectados com o auxílio de padrões de massa molecular de 25 e 10 pb (Promega Corporation, Madison, WI). As freqüências dos alelos dos genes PIT-1, bGH e IGF-1, para 443 animais, foram calculadas por meio de contagem direta.

Foram analisados 339 registros de peso ao nascimento (PN), 339 registros de peso aos 60 dias de idade (P60), 298 registros de peso aos 205 dias (P205) e 252 registros de peso aos 365 dias de idade (P365). Foram também analisados os ganhos de peso entre as idades, isto é, do nascimento aos 60 dias de idade (GP-N-60), de 60 a 205 dias (GP-60-205) e de 205 a 365 dias (GP-205-365). Os pesos foram ajustados para idades-padrão, usando fatores obtidos do próprio conjunto de dados.

A fim de estimar o efeito direto de cada alelo, os registros foram analisados por meio de um modelo de substituição gênica que estima o efeito de um alelo em particular, depois da remoção dos efeitos aditivos de outros alelos do animal. Matricialmente, este modelo pode ser representado como $\mathrm{y}=\mathrm{Xh}+\mathrm{Mm}+\mathrm{Za}+\varepsilon$, em que y é o vetor de registro de pesos e ganhos de peso; 
X e Z são matrizes de incidência relativas aos efeitos fixos e aleatórios; e h, a e $\varepsilon$ são vetores de soluções para os efeitos fixos, genético aditivo e residual, respectivamente. Ainda, m é o vetor que inclui efeitos fixos de substituição gênica para alelos dos genes PIT-1, bGH e IGF-1, representados por coeficientes de regressão; e $\mathrm{M}$ é a matriz contendo 0,1 ou 2, representando o número de cópias de determinado alelo dos genes PIT-1, bGH e IGF-1, em cada indivíduo.

Os efeitos de ano/estação do nascimento e sexo do animal foram assumidos como fixos, e os efeitos genético aditivo e residual foram assumidos como aleatórios, com distribuição normal, médias iguais a zero e variâncias $\sigma_{\mathrm{a}}^{2}$ e $\sigma_{\mathrm{e}}^{2}$, respectivamente.

Todas as análises foram realizadas por meio do procedimento MIXED do SAS (SAS Institute, 2002).

\section{Resultados e Discussão}

As freqüências dos alelos A e B do gene PIT-1 e dos genótipos $\mathrm{AA}, \mathrm{AB}$ e $\mathrm{BB}$, nas populações parentais (Holandês e Gir), foram semelhantes (Tabela 1), assim também o foram entre as populações cruzadas $F_{1}$ e $F_{2}$; todavia, as populações parentais apresentaram freqüências alélicas e genotípicas diferentes das populações cruzadas para esse gene, provavelmente em

Tabela 1. Freqüências alélicas e genotípicas dos genes PIT-1, bGH e IGF-1 observadas em 443 animais, de acordo com o grupo genético ${ }^{(1)}$.

\begin{tabular}{|c|c|c|c|c|c|c|}
\hline \multirow[t]{2}{*}{ Gene } & \multirow[t]{2}{*}{ GG } & \multicolumn{5}{|c|}{ Freqüências (\%) } \\
\hline & & \multicolumn{2}{|c|}{-----Alélicas----- } & \multicolumn{2}{|c|}{--------------Genotíl } & \multirow{2}{*}{ BB } \\
\hline PIT-1 & & $\mathrm{A}$ & $\mathrm{B}$ & AA & $\mathrm{AB}$ & \\
\hline & $\mathrm{HOL}$ & 12,50 & 87,50 & $0,00(0)$ & $25,00(1)$ & 75,00 (3) \\
\hline & GIR & 12,96 & 87,04 & $0,00(0)$ & $25,93(7)$ & $74,07(20)$ \\
\hline & $\mathrm{F}_{1}$ & 7,53 & 92,47 & $1,37(1)$ & $12,33(9)$ & $86,30(63)$ \\
\hline & $\mathrm{F}_{2}$ & 5,83 & 94,17 & $0,00(0)$ & $11,66(40)$ & $88,34(299$ \\
\hline \multirow[t]{5}{*}{ bGH } & & E & $\mathrm{F}$ & $\mathrm{EE}$ & $\mathrm{EF}$ & $\mathrm{FF}$ \\
\hline & $\mathrm{HOL}$ & 100,00 & 0,00 & $100,00(4)$ & $0,00(0)$ & $0,00(0)$ \\
\hline & GIR & 8,00 & 92,00 & $3,85(1)$ & 7,69 (2) & $88,46(24)$ \\
\hline & $\mathrm{F}_{1}$ & 63,01 & 36,99 & 26,03 & $73,97(54)$ & $0,00(0)$ \\
\hline & $\mathrm{F}_{2}$ & 54,08 & 45,92 & $30,03(102)$ & $48,10(163)$ & $21,87(74)$ \\
\hline \multirow[t]{5}{*}{ IGF-1 } & & A & B & AA & $\mathrm{AB}$ & BB \\
\hline & $\mathrm{HOL}$ & 50,00 & 50,00 & $0,00(0)$ & $100,00(4)$ & $0,00(0)$ \\
\hline & GIR & 98,15 & 1,85 & $96,30(26)$ & $3,70(1)$ & $0,00(0)$ \\
\hline & $\mathrm{F}_{1}$ & 56,16 & 43,84 & $12,33(9)$ & $87,67(64)$ & $0,00(0)$ \\
\hline & $\mathrm{F}_{2}$ & 56,70 & 43,30 & $27,70(94)$ & $58,01(197)$ & $14,29(48)$ \\
\hline
\end{tabular}

${ }^{(1)}$ GG: grupo genético; $F_{1}: 50 \%$ Holandês:50\% Gir; $F_{2}: F_{1} x F_{1}$. ${ }^{(2)}$ Número de animais observados em cada classe genotípica está entre parênteses. função da diferente intensidade de utilização de machos e fêmeas, já que as populações $F_{1}$ e $F_{2}$ foram obtidas por meio do uso da técnica de múltipla ovulação e transferência de embriões. Freqüências similares, $25 \%$ para o alelo A e $75 \%$ para o alelo B, foram relatadas por Oprzadek et al. (2003), ao estudarem associações da PIT-1 com características de crescimento numa população de touros Black and White, na Polônia. Resultados semelhantes foram obtidos por Klauzinska et al. (2000), que estudaram a freqüência alélica de PIT-1 na raça Polish Black and White, e Sabour et al. (1996), na raça Holandesa, os quais encontraram freqüências de 26 e $21 \%$, respectivamente, para o alelo A.

O gene bGH, nos animais da raça Holandesa, apresentou freqüência igual a 100\% para o alelo E e, conseqüentemente, do genótipo EE. Resultado semelhante foi obtido por Sorensen et al. (2002), quando estudaram o efeito do polimorfismo do gene PIT-1 na liberação de somatropinas, em animais da raça Danish Holstein, com freqüência de 93\% para alelo E. Ao estudarem a influência de alelos do bGH sobre características de carcaça, numa população de bovinos Polish Friesien, Grochowska et al. (2001) verificaram que os alelos E e F possuíam freqüências iguais a 69 e 31\%, respectivamente. Por sua vez, os animais da raça Gir apresentaram $92 \%$ de alelos $\mathrm{F}$ nesse gene, determinando a alta freqüência de indivíduos heterozigotos nas populações $F_{1}$ e $\mathrm{F}_{2}$. A predominância do alelo $\mathrm{F}$ em Zebuínos possivelmente é uma característica dos animais Bos indicus (Unanian et al., 2000).

Em relação ao gene IGF-1, todos os animais da raça Holandesa foram heterozigotos, ao passo que a população de animais da raça Gir era composta, quase em sua totalidade, por indivíduos homozigotos para o gene A, implicando alta freqüência de indivíduos heterozigotos nas populações cruzadas. Verificaram-se diferenças acentuadas nas freqüências alélicas e genotípicas dos genes das populações parentais estudadas, à exceção do PIT-1, o que denota a existência de variabilidade entre as raças.

Os resultados da associação entre os polimorfismos dos genes candidatos estudados e as características quantitativas medidas estão apresentados na Tabela 2. Em relação a peso ao nascimento, somente houve efeito significativo quanto ao alelo A do gene IGF-1. Esse gene atua como mediador de muitos efeitos do GH no crescimento, e o alelo A pode estar relacionado ao maior estímulo de processos anabólicos pré-natais, como divisão celular, crescimento esquelético e síntese 
Tabela 2. Efeito de substituição $(\hat{\beta})$ dos alelos IGF-1, PIT-1 e bGH e respectivos erros-padrões das características de peso ao nascimento (PN), peso aos 60 dias (P60), peso aos 205 dias (P205), peso aos 365 dias de idade (P365) e ganhos de peso do nascimento aos 60 dias (GP-N-60).

\begin{tabular}{lcccccc}
\hline Gene & Alelo & PN & P60 & P205 & P365 & GP-N-60 \\
\hline IGF-1 & A & $0,622 \pm 0,439^{* *}$ & $-0,451 \pm 0,642$ & $0,497 \pm 1,788$ & $2,150 \pm 2,720$ & $-0,015 \pm 0,009^{*}$ \\
PIT-1 & A & $-0,858 \pm 0,886$ & $2,411 \pm 1,296^{*}$ & $6,270 \pm 3,469^{*}$ & $14,190 \pm 5,280^{* * *}$ & $0,036 \pm 0,018^{* *}$ \\
bGH & E & $-0,017 \pm 0,395$ & $0,813 \pm 0,578$ & $1,221 \pm 1,588$ & $4,580 \pm 2,360^{* *}$ & $0,019 \pm 0,008^{* *}$ \\
\hline
\end{tabular}

${ }^{*},{ }^{* *}$ e ${ }^{* * *}$ Significativo a 10,5 e $1 \%$ de probabilidade, respectivamente.

protéica. Os efeitos do GH, mediados pelo IGF-1, sobre o crescimento dos tecidos musculares e esqueléticos são semelhantes aos da insulina, ao passo que o efeito direto do GH sobre o metabolismo de carboidratos e lipólise é antagônico ao da insulina, sendo sinergético com o cortisol nas ações lipolítica e diabetogênica. O IGF-1 é o agente mediador da maioria dos efeitos do hormônio de crescimento no desenvolvimento muscular (Zulu et al., 2002).

O P365 e o GP-N-60 foram influenciados significativamente pelo alelo E do gene bGH (Tabela 2). Possivelmente, a influência do GH sobre a regulação do crescimento e no desenvolvimento dos diferentes tecidos explique essa associação. Este resultado é conflitante com o encontrado por Unanian et al. (2000), que não encontraram associações significativas entre o polimorfismo do bGH (Hae III) e ganhos de peso em diversas idades de animais da raça Nelore. Segundo esses autores, tal polimorfismo tem sido associado à qualidade de carcaça (porcentagem de ácidos graxos), e a ausência de associação pode se relacionar ao tamanho reduzido da amostra estudada e à estrutura da população exogâmica (rebanho comercial).

Foram também encontradas associações significativas do alelo A do gene PIT-1 com P60, P205, P365 e GP-N-60. Estudos bioquímicos têm revelado que PIT-1 é um fator de transcrição célula-específico crítico para a ativação da expressão da prolactina, do GH e do gene do hormônio estimulante da tiróide. Esse mesmo gene está associado à ativação de outros hormônios, como o receptor de GH, que media as ações do GH nas célulasalvo por meio da tradução de sinais miogênicosestimulantes através da membrana celular. A inibição da síntese de PIT-1 leva à diminuição acentuada da expressão da prolactina e de GH, e mutações nesse gene são responsáveis pelo nanismo em algumas espécies. A influência de PIT-1, nessas características, possivelmente ocorreu em razão da associação entre esse gene e o desenvolvimento corporal. Conde et al. (2001) encontraram associação significativa entre os alelos PIT-1 e o peso à desmama de bovinos Nelore. Por sua vez, Moody et al. (1996) mostraram que, além do peso ao desmame, o PIT-1 estava relacionado a maiores pesos aos 365 dias de idade. De acordo com Conde et al. (2001), tais resultados fortalecem a hipótese deste gene ser um marcador útil, em programas de seleção assistida por marcadores, que busquem precocidade e maior desenvolvimento corporal nos primeiros meses de vida.

Os resultados indicam que os três genes podem ser utilizados como marcadores para precocidade; todavia, deve-se considerar que os animais dessa população foram criados sob sistema de alimentação com restrição alimentar, tanto na fase de cria, quanto na recria, o que pode ter impedido a expressão do potencial dos animais de maior exigência. Os animais utilizados são oriundos de raças exploradas para produção de leite. Em raças selecionadas para maior produção de carne, o efeito dos genes poderia ser maior, em razão dos objetivos de seleção.

Segundo Brunsch et al. (2002), a detecção do efeito direto de genes candidatos, em uma população experimental composta por indivíduos $F_{2}$, deve ser posteriormente validada em raças ou linhagens comerciais.

\section{Conclusões}

1. O gene PIT-1 está associado a maiores ganhos de peso em sistemas com restrição alimentar.

2. O gene IGF-1 pode ser usado como critério de seleção para a obtenção de menor peso ao nascimento, sem impacto no peso à desmama e ao sobreano.

3. O bGH tem efeito inconsistente, que desaparece depois de 60 dias. 


\section{Agradecimentos}

Ao CNPq e à Fapemig, pela concessão de bolsas de apoio técnico; à Embrapa-Prodetab, pelo apoio financeiro.

\section{Referências}

ABDEL-AZIM, G.; FREEMAN, A.E. Superiority of QTL-assisted selection in dairy cattle breeding schemes. Journal of Dairy Science, v.85, p.1869-1880, 2002.

BERNAL, M.G. Avances en producción de leche: la somatotropina. Veterinaria México, v.21, p.409-414, 1990.

BRUNSCH, C.; STERNSTEIN, I.; REINECKE, P.; BIENIEK, J. Analysis of association of PIT1 genotypes with growth, meat quality and carcass composition traits in pigs. Journal of Applied Genetics, v.43, p.85-91, 2002.

CONDE, S.B.; GUIMARÃES, S.E.F.; EUCLYDES, R.F.; SILVA, L.O.C.; EUCLYDES, F.K. Marcadores moleculares associados com crescimento em bovinos. Revista Brasileira de Reprodução Animal, v.25, p.485-486, 2001.

GE, W.; DAVIS, M.E.; HINES, H.C.; IRVIN, K.M.; SIMMENS, R.C.M. Association of a genetic marker with blood serum insulinlike growth factor-I concentration and growth traits in Angus cattle. Journal of Animal Science, v.79, p.1757-1762, 2001.

GROCHOWSKA, R.; LUNDÉN, A.; ZWIERZCHOWSKI, L.; SNOCHOWSKI, M.; OPRZADEK, J. Association between gene polymorphism of growth hormone and carcass traits in dairy bulls. Animal Science, v.72, p.441-447, 2001.

ISAKSSON, O.G.; EDEN, S.; JANSSON, J.O. Mode of action of pituitary growth hormone on target cells. Annual Review of Physiology, v.47, p.483-499, 1985.

KLAUZINSKA, M.; ZWIERZCHOWSKI, L.; SIADKOWSKA, E.; SZYMANOWSKA, M.; GROCHOWSKA, R.; ZURKOWSKI, $M$. Comparison of selected gene polymorphisms in Polish Red and Polish Black-and-White cattle. Animal Science Papers and Reports, v.18, p.107-116, 2000.

LUCY, M.C.; HAUSER, S.D.; EPPARD, P.J.; KRIVI, G.G.; CLARK, J.H.; BAUMAN, D.E.; COLLIER, R.J. Genetic polymorphism within the bovine somatotropin (bST) gene detected by polymerase chain reaction and endonuclease digestion. Journal of Dairy Science, v.74, p.284, 1991.

MILLER, J.R.; THOMSEN, P.D.; DIXON, S.C.; TUCKER, E.M.; KONFORTOV, B.A.; HARBITZ, I. Synteny mapping of the bovine IGHG2, CRC and IGF1 genes. Animal Genetics, v.23, p.51-58, 1991.
MOODY, D.E.; POMP, D.; NEWMAN, S.; MacNEIL, M.D. Characterization of DNA polymorphisms in three populations of Hereford cattle and their associations with growth and maternal EPD in line 1 herefords. Journal of Animal Science, v.74, p.17841793, 1996.

NEATHERY, M.W.; CROWE, C.T.; HARTNELL, G.F.; VEENHUIZEN, J.J.; REAGEN, J.O.; BLACKMON, D.M. Effects of sometribove on performance, carcass composition, and chemical blood characteristics of dairy calves. Journal of Dairy Science, v.74, p.3933-3939, 1991.

OPRZADEK, J.; FLISIKOWSKI, K.; ZWIERCHOWSKI, L.; DYMNICKI, E. Polymorphisms at loci of leptin (LEP), Pit1 and STAT5A and their association with growth, feed conversion and carcass quality in Black-and-White bulls. Animal Science Papers and Reports, v.21, p.135-145, 2003.

RENAVILLE, R.; GENGLER, N.; PARMENTIER, I.; MORTIAUX, F.; MASSART, S.; BERTOZZI, C.; BURNY, A.; PORTETELLE, D. Pit-1 gene Hinf I RFLP and growth traits in double-muscled Belgian Blue cattle. Journal of Animal Science, v.75, p.146, 1997a. Supplement 1.

RENAVILLE, R.; GENGLER, N.; VRECH, E.; PRANDI, A.; MASSART, S.; CORRADINI, C.; BERTOZZI, C.; MORTIAUX, F.; BURNY, A.; PORTETELLE, D. Pit-1 gene polymorphism, milk yield, and conformation traits for Italian Holstein-Friesian bulls. Journal of Dairy Science, v.80, p.3431-3438, 1997b.

SABOUR, M.P.; LIN, C.Y.; LEE, A.J.; MACLLISTER, A.J. Association between milk protein variants and genetic values of Canadian Holstein bulls for milk yield traits. Journal of Dairy Science, v.79, p.1050-1056, 1996.

SAS INSTITUTE (Cary, Estados Unidos). SAS/STAT user's guide. Version 8.0. Cary, 2002. 5v.

SORENSEN, P.; GROCHOWSKA, R.; HOLM, L.; HENRYON, M.; LOVENDAHL, P. Polymorphism in the bovine growth hormone gene affects endocrine release in dairy calves. Journal of Dairy Science, v.85, p.1887-1893, 2002.

UNANIAN, M.M.; BARRETO, C.C.; FREITAS, A.R.; CORDEIRO, C.M.T.; JOSAHKIAN, L.A. Associação do polimorfismo do gene do hormônio do crescimento com a característica peso em bovinos da raça Nelore. Revista Brasileira de Zootecnia, v.29, p.1380-1386, 2000.

WOOLARD, J.; SCHMITZ, C.B.; FREEMAN, A.E.; TUGGLE, C.K. Rapid communication: Hinf I polymorphism at the bovine Pit-1 locus. Journal of Animal Science, v.72, p.3267, 1994.

ZULU, V.C.; NAKAO, T.; SAWAMUKAI, Y. Insulin-like growth factor-I as a possible hormonal mediator of nutritional regulation of reproduction in cattle. Journal of Veterinary Medical Science, v.64, p.657-665, 2002.

Recebido em 11 de fevereiro de 2005 e aprovado em 21 de agosto de 2005 